Orijinal Araștırma

\title{
Psoriasis ve metabolik sendrom
}

\section{Psoriasis and metabolic syndrome}

Aslı Günaydın, Derya Aytimur*, Fezal Özdemir*

Artvin Devlet Hastanesi, Deri ve Zührevi Hastalıkları Kliniği, Artvin, Türkiye

*Ege Üniversitesi Tıp Fakültesi, Deri ve Zührevi Hastalıkları Anabilim Dalı, İmir, Türkiye

\section{Özet}

Amaç: Psoriasis, poligenik faktörler ve tetikleyici etkenler zemininde ortaya çıkan kronik, inflamatuvar bir deri hastalığıdır. Günümüzde sistemik bir hastalık olarak kabul gören psoriasisin başka hastalıklarla da ilişkisi kanıtlanmıştı. Kardiyovasküler hastalıklar, karaciğer yağlanması, obezite, diyabetes mellitus, hipertansiyon ve hiperlipidemi bu hastalıkların başıcalarıdır.

Gereç ve Yöntem: Bu çalışmada 50 yetişkin psoriasis olgusunun açlık kan glukozları, serum lipid değerleri (total kolesterol, HDL kolesterol, LDL kolesterol, trigliserid), bazal insülin değerleri, insülin dirençleri ve vücut kitle indeksleri, sigara ve alkol alışkanlıkları, yaş-cinsiyet eşleştirmeli 50 non-psoriatik kontrol olgu grubu ile karşılaştırımışırı.

Bulgular: Çalışmamızda psoriatik olguların \%62'sinde metabolik sendrom saptanırken bu oran non-psoriatik kontrol grubunda \%24'dü ve aralarındaki fark istatistiksel olarak anlamlı bulundu. Hasta grubunda metabolik sendromu olanların medyan PAşi değeri 13,6 iken, metabolik sendromu olmayanların medyan PAşi değeri 11,2 idi ve fark istatistiksel olarak anlamlı bulundu.

Sonuç: Çalışmamızda psoriasis olgularında metabolik sendrom ve komponentleri olan diyabetes mellitus, obezite, hipertansiyon, dislipidemi kontrol grubuna kıyasla daha yüksek oranda saptanmıştır. (Türkderm 2014; 48: 95-9)

Anahtar Kelimeler: Komorbidite, metabolik sendrom, psoriasis

\section{Summary}

Background and Design: Psoriasis is a chronic, inflammatory disease that occurs with polygenic and other triggering factors. The association of psoriasis, which is considered to be a systemic disease, with other diseases, such as cardiovascular diseases, hepatosteatosis, obesity, diabetes mellitus, hypertension, and hyperlipidemia has been shown.

Materials and Methods: In this study, we compared the levels of fasting blood glucose, serum lipid (total cholesterol, HDL cholesterol, triglyceride), basal insulin, insulin resistance and body mass index as well as cigarette and alcohol consumption in 50 adult patients with those in 50 age- and gender-matched non-psoriatic controls.

Results: In our study, metabolic syndrome was present in $62 \%$ patients with psoriasis, compared with $24 \%$ of the controls ( $p<0,001)$. In psoriatic patients with metabolic syndrome PASI median value was 13,6, whereas patients without metabolic syndrome PASI median value was 11,2 and the difference was statistically significant $(p<0,001)$.

Conclusion: In our study, the frequency of metabolic syndrome and its components diabetes mellitus, obesity, hypertension, and dyslipidemia were found to be higher in patients with psoriasis compared to that in non-psoriatic controls. (Turkderm 2014; 48: 95-9)

Key Words: Comorbidity, metabolic syndrome, psoriasis 


\section{Giriş}

Psoriasis, poligenik faktörler ve tetikleyici etkenler zemininde ortaya çıkan kronik, inflamatuvar bir deri hastalı̆ı̆ır. Toplumda \%2 sıklıkta görülmekte olup eritemli, skuamlı, keskin sınırlı plaklarla karakterizedir. Lezyonlar en sık saçlı deri, diz-dirseklerde yerleşir, bu alanları tırnaklar, gövde ve eller izlemektedir. Her yaşta görülebilmekle birlikte $20-30$ ve 50-60 yaşları arasında iki pik yapmaktadır. Psoriasisin ortaya çıkısında genetik faktörler önemli bir yere sahiptir ve olguların ailesinde psoriasis varlığı öyküsü \%35-\%90 arasında değişmektedir. Genetik yatkınlığı olan bireylerde dışsal ve içsel tetikleyici faktörler de hastalı̆ın ortaya çıkışına zemin hazırlamaktadır. Travma, ultraviyole maruziyeti dışsal faktörlere; infeksiyonlar, endokrinolojik hastalıklar, stres, ilaçlar, alkol ve sigara bağımlılığı içsel faktörlere örnek gösterilebilir ${ }^{1,2}$.

Psoriasisin komorbiditeleri ise iki ana grupta incelenebilir3;

1. Aynı patogenetik mekanizmalarla oluşanlar (Crohn hastalığı, psoriatik artrit)

2. Kronik, yaygın inflamasyon sonucu oluşanlar (kardiyovasküler hastalıklar (KVH), metabolik sendrom vs.)

$\mathrm{KVH}$ ve metabolik sendrom grubu komorbiditelerden Th1 aracılı kronik inflamasyonun sorumlu olduğu düşünülmektedir4.

Metabolik sendrom; DM, hipertansiyon $(\mathrm{HT})$, obezite ve hiperlipideminin kombinasyonudur.

Türkiye Endokrinoloji Metabolizma Derneği, Metabolik Sendrom Çalışma Grubu, Metabolik Sendrom tanı kriterlerine göre metabolik sendrom tanısı için Tablo 1'deki şartlar gerekmektedir5. Son zamanlarda metabolik sendromun kronik, düşük dereceli bir inflamasyonla ilişkili olduğu saptanmıştır6,7.

$\mathrm{Bu}$ ilişkinin belirlenmesinin ardından psoriasis ve metabolik sendrom birlikteliği ile ilgili çok sayıda çalışma yapılmıştır. Psoriatik olgularda metabolik sendrom sıklığının normal popülasyonla kıyaslandığında yüksek saptanmasının yanı sıra metabolik sendromu oluşturan verilerden serum lipid değerlerinin veya obezite görülme sıklığının farklılık gösterdiği görülmektedir8-12.

Biz de çalışmamızda, psoriatik olgularda, sağlıklı kontrol grubuyla kıyaslandığında metabolik sendrom sıklığının artmış olduğu hipotezini desteklemek ve metabolik sendrom kriterlerini oluşturan parametreler ile ilgili değişken verilere katkıda bulunmayı amaçladık.

\section{Gereç ve Yöntem}

Çalışma, Ocak 2011-Nisan 2011 tarihleri arasında polikliniğimize başvuran, 18 yaşından büyük, klinik ve histopatolojik olarak plak tipi psoriasis tanısı almış 50 hasta ve non-psoriatik 50 kontrol olgusu ile yapıldı. Hasta ve kontrol grubu sayı, cinsiyet ve yaş eşleştirilmeli seçildi. Çalışma prospektif, kontrollü olup, Kinik Araştırmalar Etik Komitesi'ne başvurularak etik kurul onayı alındı.

Hasta grubunda çalışmaya dahil edilme kriterleri:

1. 18 yaşından büyük olmak.

2. Klinik ve histopatolojik olarak plak tipi psoriasis tanısı almış olmak.

3. Son altı aydır psoriasise yönelik sistemik tedavi almamış olmak.

4. Son üç aydır psoriasise yönelik topikal tedavi almamış olmak.

5. Bilgilendirilmiş gönüllü olur formunu okuyup, onaylamak.

Kontrol grubu, dermatoloji polikliniğine başvuran, inflamatuvar hastalığı bulunmayan (psoriasis, Crohn hastalığı, ülseratif kolit, bağ dokusu hastalığı, aterosklerotik kalp hastalığı vb.) olgulardan seçildi.
Her iki grup için de; DM, HT, dislipidemi, KVH, kronik karaciğer hastalığı, hipotiroidi tanısı olanlar, anti-hiperlipidemik, anti-diyabetik, antipsikotik ilaç kullananlar ve gönüllü olur formunu onaylamayanlar çalışmaya alınmadı.

Her iki grubun da tansiyon arteriyel, boy, kilo, bilateral iliyak çıkıntılardan geçecek ve yere paralel olacak şekilde, ekspiryum sonunda mezure ile bel çevresi ölçümleri yapıldı.

On iki saatlik açlık sonrası kan örnekleri alındı. Biyokimya Anabilim Dalı Araştırma Laboratuvarı́nda açlık kan glukozu, kolesterol, trigliserid, LDL- kolesterol, HDL-kolesterol değerleri, Endokrinoloji Laboratuvarı'nda bazal insülin değerleri çalışıldı. Olguların VKi'leri, kiloları (kg cinsinden), boylarının (metre cinsinden) karelerine bölünerek hesaplandı.

Insülin direncini saptamak için HOMA-IR (The Homeostasis Model Assessment of Insulin Resistance) parametresi; açlık kan glukozu $(A K G=m g / d L)$ ve açlık insülin $(A l=\mu l \mathrm{U} / \mathrm{ml})$ değerlerinin çarpılıp 405'e bölünmesiyle elde edildi (HOMA-IR=AKGxAl/405). Metabolik sendrom varlığı, Türkiye Endokrinoloji Metabolizma Derneği, Metabolik sendrom Çalışma Grubu, Metabolik sendrom tanı kriterleri ile değerlendirildi (Tablo 1).

Elde edilen verilerin istatistiksel analizi, bilgisayar ortamında "SPSS for WiNDOWS 19.0" programı ile yapıldı. Kategorik verilerde gruplar arası karşılaştırma için çapraz tablolar oluşturuldu ve "chi square" analizi yapıldı. Grup karşılaştırmalarında, numerik değişkenlerde (normal dağılım gösteren) T-test, diğerlerinde Mann - Whitney $U$ test analizi yapıldı. Numerik değişkenler arası ilişkiyi değerlendirmek için Pearson korelasyon katsayısı hesaplandı, istatistik önemlilik eşik düzeyi olarak 0,05 alındı.

\section{Bulgular}

Çalışmaya toplam 50 hasta ve hastalarla yaş, cinsiyet açısından eşleştirilmiş 50 kontrol olgusu dahil edildi. Her iki grupta da 25 kadın ve 25 erkek olgu mevcuttu.

Yaş açısından eşleştirilmiş olan gruplarda hasta grubunun yaş ortalaması $45,86( \pm 1,95)$ (Tablo 2), kontrol grubunun yaş ortalaması 45,72 $( \pm 1,96)$ idi ve aralarında anlamlı fark yoktu $(p=0,9)$.

Hasta grubundakilerin \%58'i (n=29), kontrol grubundakilerin \%34'ünde ( $n=17)$ sigara içme alışkanlığı mevcuttu ve bu fark chi-square test ile karşılaştırılı̆̆ında, istatistiksel olarak anlamlıydı $(p=0,016)$.

Tablo 1. Türkiye Endokrinoloji Metabolizma Derneği, Metabolik Sendrom Çalışma Grubu, Metabolik Sendrom Tanı Kriterleri(5)

Aşağıdakilerden en az biri:

- Diyabetes mellitus veya

- Bozulmuş glukoz toleransı veya

- Insülin direnci ve

\section{Aşağıdakilerden en az ikisi:}

Hipertansiyon (sistolik kan basıncı >130, diyastolik kan basıncı >85 $\mathrm{mmHg}$ veya antihipertansif kullanıyor olmak)

- Dislipidemi (trigliserid düzeyi $>150 \mathrm{mg} / \mathrm{dl}$ veya $\mathrm{HDL}$-kolesterol

düzeyi erkekte $<40 \mathrm{mg} / \mathrm{dl}$, kadında $<50 \mathrm{mg} / \mathrm{dl}$ )

- Abdominal obezite $\left(\mathrm{VKi}>30 \mathrm{~kg} / \mathrm{m}^{2}\right.$ veya bel çevresi: erkeklerde $>94 \mathrm{~cm}$, kadınlarda $>80 \mathrm{~cm}$ )

VKI: Vücut Kitle Indeksi 
Hasta grubunun VKi medyan değeri 27,0 $( \pm 5,2)$, kontrol grubunun VK medyan değeri $27,5( \pm 5,4)$ olarak hesaplandı, T-test ile karşılaştıııldığında aralarında istatistiksel olarak anlamlı fark yoktu $(p=0,69)$.

Hasta grubunun medyan bazal insülin değeri 9,29 $( \pm 8,9)$ iken kontrol grubunun $4,1( \pm 5,3)$ idi ve fark Mann-Whitney $U$ test ile karşılaştıııldığında anlamlı bulundu ( $<<0,01)$ (Tablo 3).

Hasta grubunun medyan total kolesterol değeri 198,5 ( \pm 56$)$ iken kontrol grubunun 199,50 ( \pm 48$)$ idi. Sonuç T test ile değerlendirildiğinde anlamlı fark bulunmadı $(p=0,36)$.

Hasta grubunun medyan LDL kolesterol değerleri 125,50 ( \pm 39$)$ iken, kontrol grubunun medyan LDL kolesterol değeri 123,0 ( \pm 42$)$ idi. Fark T test ile değerlendirildiğinde anlamsı bulundu $(p=0,35)$.

Hastaların medyan serum trigliserid değerleri 134,0 ( \pm 74$)$ iken kontrol grubunun medyan değeri $114,5( \pm 55)$ idi ve fark $T$ testle anlamlı bulundu $(p=0,042)$.

Hasta grubunun medyan HDL kolesterol değeri 45,50 ( \pm 14$)$, kontrol grubunun medyan değeri 45,50 $( \pm 16)$ idi. Fark $T$ test ile değerlendirildiğinde anlamlı değildi $(p=0,7)$.

Hasta grubunun bel çevresi medyan değeri $100( \pm 16)$ iken kontrol grubunun medyan değeri $92( \pm 17)$ olarak hesaplandı. Aralarındaki fark $T$ test ile değerlendirildiğinde istatistiksel olarak anlamlıydı $(p<0,001)$. Hasta grubundaki olguların \%62'sinde $(n=31)$ metabolik sendrom saptanırken bu oran kontrol grubunda \%24'dü $(n=12)$. Bu oran chisquare test ile anlamlı bulundu ( $p<0,001)$ (Tablo 4).

Hasta grubundaki olguların medyan AKG değeri 98 ( \pm 13$)$ iken, kontrol grubundaki olguların medyan AKG değeri $91( \pm 10)$ idi. Bu fark T test ile hesaplandığında istatistiksel olarak anlamlı bulundu $(p<0,001)$.

Her iki grubun HOMA-IR medyan değeri karşılaştıııldığında, hasta grubunda 2,2 $( \pm 2,05)$, kontrol grubunda ortalama $0,9( \pm 1,1)$ idi ve fark

\section{Tablo 2. Hasta grubunun demograffk özellikleri}

\begin{tabular}{|c|c|c|}
\hline & $\mathrm{n}$ & $\%$ \\
\hline \multicolumn{3}{|l|}{ Cinsiyet } \\
\hline Kadın & 25 & 50 \\
\hline Erkek & 25 & 50 \\
\hline \multicolumn{3}{|l|}{ Yaş } \\
\hline $18-30$ & 7 & 14 \\
\hline $31-50$ & 24 & 48 \\
\hline 51 ve üzeri & 19 & 38 \\
\hline Sigara kullanım öyküsü (+) & 29 & 58 \\
\hline \multicolumn{3}{|l|}{ PAşi } \\
\hline$<10$ & 20 & 40 \\
\hline$>10$ & 30 & 60 \\
\hline
\end{tabular}

Tablo 3. Hasta ve kontrol grubunda ortalama bazal insülin değerlerinin karşılaştırılması

\begin{tabular}{|l|l|l|}
\hline & Hasta Grubu & Kontrol Grubu \\
\hline Bazal İnsülin Değeri & 9,3 & 4,1 \\
\hline
\end{tabular}

Tablo 4. Psoriatik hasta grubunda ve kontrol grubunda metabolik sendrom varlığının karşılaştırılması

\begin{tabular}{|l|l|l|}
\hline & Hasta grubu & Kontrol Grubu \\
\hline Metabolik Sendrom Varlığı & 31 & 12 \\
\hline
\end{tabular}

Mann Whitney $U$ test ile istatistiksel olarak anlamlı bulundu $(p<0,001)$. Hasta grubundaki olguların \%26'sında ( $n=13$ ) kontrol grubundaki olguların ise \%14'ünde ( $n=7)$ HT mevcuttu. Aralarındaki fark chi square test ile anlamlı bulunmadı $(p=0,21)$.

Hasta grubunda, erkeklerde medyan PAŞi değeri 13,2 $( \pm 5,4)$ iken, kadınlarda 10,7 $( \pm 8,3)$ idi. Cinsiyet ve PAŞi değeri arasındaki Mann Whitney $U$ tesi ile anlamlı bulunmadı $(p=0,7)$.

Hasta grubunda sigara içme öyküsü olanların medyan PAŞi değeri 12,4 $( \pm 7,2)$, sigara içme öyküsü olmayanların medyan PAŞi değeri 10,9 $( \pm 6,4)$ olarak saptandı ancak fark Mann Whitney $U$ testi ile istatistiksel olarak anlamlı bulunmadı $(p=0,6)$.

Hasta grubundaki PAŞi ve VKi arasındaki ilişki pearson korelasyon analizi ile değerlendirildiğinde anlamlı değildi $(p=0,59)$.

Psoriatik olguların psoriasis süresi ile VKi arasındaki ilişki pearson korelasyon analizi ile değerlendirildiğinde anlamlı değildi $(p=0,66)$.

Hasta grubunda, sigara içme öyküsü olanların medyan VKi değeri 26,8 $( \pm 6,2)$ iken sigara içme öyküsü olmayanların medya VKi değeri 27,8 $( \pm$ $6,4)$ idi. Fark, $T$ test ile anlamlı bulunmadı $(p=0,18)$.

Kontrol grubunda sigara içme öyküsü olanların medyan VKi değeri 27,0 $( \pm 6,2)$ iken, sigara içme öyküsü olmayanların medyan VKi değeri 27,5 $( \pm 5,2)$ idi. Aralarındaki fark T test ile anlamlı bulunmadı $(p=0,50)$.

Hasta grubunda PAŞi ve bazal insülin değerleri Pearson korelasyon analizi ile karşılaştııılığında aralarında anlamlı ilişki saptanmadı $(p=0,70)$.

Psoriatik olguların hastalık süresi ile bazal insülin değerleri Pearson korelasyon analizi ile karşılaştııılığında aralarında istatistiksel olarak anlamlı ilişki saptanmadı ( $p=0,37)$.

Hasta grubundaki olguların PAşi ve hastalık süresinin, kolesterol değeri ile arasındaki ilişki Pearson korelasyon analizi ile değerlendirildiğinde anlamlı bulunmadı $(p=0,051)$.

Hasta grubunda metabolik sendromu olanların medyan PAşi değeri 13,6 $( \pm 8,1)$ iken, metabolik sendromu olmayanların medyan PAŞi değeri 11,2 $( \pm 6,9)$ idi. Aralarındaki fark $T$ test ile hesaplandığında anlamlı bulundu $(p=0,04)$.

Hasta grubundaki kadınların \%72'sinde, erkeklerin \%52'sinde metabolik sendrom mevcuttu. Aralarındaki ilişki chi-square test ile incelendiğinde anlamlı bulunmadı $(p=0,12)$.

Hasta grubunda metabolik sendromu olanların yaş ortalaması 49,0 $( \pm 18)$ iken, metabolik sendromu olmayanların yaş ortalaması 40,0 $( \pm 30)$ idi. Aralarındaki ilişki T test ile incelendiğinde istatistiksel olarak anlamlı bulunmadı $(p=0,15)$.

Metabolik sendromu olan psoriatik olgularda medyan hastalık süresi 12 ay $( \pm 26)$ iken, metabolik sendromu olmayanlarda medyan hastalık süresi 14 ay $( \pm 42)$ idi. Aralarındaki ilişki Mann Whitney $U$ test ile değerlendirildiğinde anlamlı bulunmadı $(p=0,88)$.

Hasta grubunda açlık kan glukozu ve HOMA-IR ile PAŞi arasındaki ilişki Pearson korelasyon analizi ile değerlendirildiğinde anlamlı bulunmadı (sırasılyla $p=0,11$ ve $p=0,98$ ).

Hasta grubunda yaş ve HOMA-IR arasındaki ilişki Pearson korelasyon analizi ile incelendiğinde anlamlı bulundu $(p=0,012)$. Aynı şekilde, kontrol olgularının yaşları ve HOMA-IR değeri arasında Pearson korelasyon analizi ile anlamlı ilişki saptandı $(p=0,041)$.

Sigara içme öyküsü olan psoriatik olgularda medyan HOMA-IR değeri $2,04( \pm 1,8)$, sigara içmeyenlerde ise $2,6( \pm 2,25)$ idi. Aralarındaki ilişki Mann Whitney $U$ test ile incelendiğinde anlamlı bulunmadı $(p=0,44)$. Kontrol grubunda VKi ve HOMA-IR değeri arasındaki ilişki Pearson korelasyon analizi ile değerlendirildiğinde anlamlı bulundu $(p=0,009)$. 
Kontrol grubunda, kadın olguların medyan VKi değeri 27,0 $( \pm 6,5)$ iken, erkek olguların medyan VKi değeri $28,4( \pm 5,2)$ idi. Aralarındaki fark T test ile incelendiğinde anlamlı bulunmadı $(p=0,50)$.

\section{Tartışma}

Psoriasis toplumda \%1-\%3 sıklıkta görülen, kronik inflamatuvar bir deri hastalığıdır. Son yıllarda psoriasisin sistemik bir hastalık olduğu anlaşımış ve $\mathrm{DM}, \mathrm{HT}, \mathrm{KVH}$, obezite gibi birçok hastalıkla ilişkisi kanıtlanmıştır2. Komorbiditeler ve psoriasis arasındaki ilişki bazı hastalıklarda ortak patogenetik mekanizmalar (Crohn hastalı̆ıı, psoriatik artrit) ${ }^{13}$ bazı hastalıklarda ise kronik inflamasyon ( $\mathrm{KVH}$, metabolik sendrom $)^{14}$ ile açıklanmaktadır. Bu nedenle, çalışmamızda, sağlıklı ve objektif bir karşılaştırma yapabilmek için, kontrol grubunu, polikliniğimize başvuran ve inflamatuvar hastalığı bulunmayan (psoriasis, bağ dokusu hastalığı, $\mathrm{KVH}$ vb.) olgulardan seçtik.

Son yıllarda psoriasis kardiyak hastalık açısından bağımsız risk faktörü olarak kabul görmekte ve metabolik sendrom ile de yakından ilişkili olduğu bilinmektedir15-18. Psoriatik olgularda metabolik sendrom insidansı ve $\mathrm{KVH}$ riski PAŞi ile ilişkilendirilmiş, tutulan vücut yüzey alanı daha fazla, hastalık süresi daha uzun olanlarda riskin arttığı belirlenmiştir ${ }^{19}$.

Çalışmamızda psoriatik olguların \%62'sinde metabolik sendrom saptanırken bu oran non-psoriatik olgularda \%24'dü ve aralarındaki fark istatistiksel olarak anlamlı bulundu. Hasta grubunda metabolik sendromu olanların medyan PAŞi değeri 13,6 iken, metabolik sendromu olmayanların medyan PAŞi değeri 11,2 idi ve fark istatistiksel olarak anlamlıydı. Psoriatik kadınların \%72'sinde, erkeklerin \%52'sinde metabolik sendrom mevcuttu ancak fark istatistiksel olarak anlamlı bulunmadı. Sonuç olarak çalışmamızda, psoriatik olgularda metabolik sendrom sıklığı kontrol grubuna göre artmıştı ve bu artış PAŞi değeri ile korele seyretmekteydi.

Klinikte insülin direncinin göstergesi olan HOMA-IR medyan değeri ise hasta grubunda 2,2, kontrol grubunda 0,9 idi ve bu fark da istatistiksel olarak anlamlı bulundu.

Uzun süredir psoriasis anamnezi olanlarda asitretin, siklosporin gibi sistemik ajanların kullanımının da insülin direncini arttırabileceği bildirilmiştir20. Aynı zamanda psoriatik olguların uzun süre topikal steroid tedavisi kullandıkları bu nedenle steroidlerin sistemik absorbsiyonunun da DM'ye yatkınlık oluşturabileceği ileri sürülmüştür21. Ancak çalışmamızdaki psoriatik olguların son üç aydır topikal tedavi almadığı ve çoğu hastanın daha önce hiç sistemik tedavi kullanmadığı göz önünde bulundurulursa psoriasisin, uygulanan tedaviden bağımsız olarak, tek başına DM riskini arttırdığı kanısındayız.

Yapılan çalışmalarda psoriatik olguların lipid profiliyle ilgili değişken veriler elde edilmiştir. Filizci ve ark.'nın8 50 psoriasis ve 30 kontrol olgusu ile yaptığı çalışmada psoriatik olguların total kolesterol ve LDL kolesterol değerleri kontrol grubuna kıyasla yüksek bulunmuştur. Uyanık ve ark.'nın9 yaptığı 72 psoriasis ve 30 kontrol olgusundan oluşan çalışmada, psoriatik olguların total kolesterol, LDL ve HDL kolesterol değerlerinde kontrol grubuna kıyasla anlamlı fark gözlenmezken, trigliserid değerindeki yükseklik anlamlı bulunmuştur. Pişkin ve ark.'nın ${ }^{10} 100$ psoriatik ve 100 kontrol olgusuyla yaptığı çalışmada, psoriatik olgularda total kolesterol ve LDL kolesterol kontrol grubuna göre anlamlı yüksek bulunurken, trigliserid ve HDL değerlerinde anlamlı fark gözlenmemiştir.
Bizim çalışmamızda her üç değer için de (total kolesterol, LDL, HDL) hasta ve kontrol grubu arasındaki fark istatistiksel olarak anlamlı değildi. Ancak psoriatik grubun medyan serum trigliserid değeri 134,0 iken kontrol grubunun medyan trigliserid değeri 114,5 idi ve fark istatistiksel olarak anlamlıydı. Hasta grubundaki olguların PAşi ve hastalık süresinin, kolesterol değeri ile arasındaki ilişki istatistiksel olarak değerlendirildiğinde anlamlı bulunmadı. Bu durumu, çalışmamızdaki hasta sayısının kısıtlı, olguların ortalama PAŞi değerlerinin nispeten düşük, dolayısıyla psoriasis kliniğinin hafif/orta şiddette olmasına bağlayabiliriz. Bunun yanı sıra çalışmamızdaki psoriasisli hastaların hastalık süresi de nispeten kısa idi (4-36 ay). Aynı hastaların uzun süre izlenmesi ile gelecekte hiperlipidemi riskinin artmış bulunabileceğ kanısındayız.

Literatürde psoriatik olguların VKi'nin normal popülasyona kıyasla yüksek olduğunu bildiren çalışmaların yanında iki grup arasında anlamlı fark olmadığını bildiren çalışmalar da mevcuttur22.

Herron ve ark.'nın23 yaptığı bir çalışmada genç erişkin psoriatik olgularda normal popülasyona kıyasla obezitenin aynı oranda görüldüğü ancak yaşla birlikte obezite sıklığının normal popülasyondan daha yüksek oranda görülmeye başlandığı belirtilmiş ve bu durum psoriasisin kümülatif inflamatuvar etkisine bağlanmıştır. Çelik ve ark.'nın ${ }^{11}$ yaptığı 100 psoriasis hastasının 100 kontrol hastası ile metabolik sendrom açısından karşılaştırıldığı çalışmada, psoriatik olgularda metabolik sendrom sıklığında istatistiksel olarak anlamlı yükseklik bulunmamış; bu durum çalışmadaki hastaların PAşi ortalamalarının düşük ve hastalık sürelerinin kısa olmasına bağlanmıştır. Biz de, psoriatik olguların medyan VKI değeri ile kontrol grubunun medyan VKi değeri arasında anlamlı bir fark bulamadık.

Ancak, VKi'nin KVH, HT, DM gibi komorbidite risklerini direkt yansıtmadığı, bel çevresi ölçüsünün komorbid durumlarla daha yakın korelasyon gösterdiği kanıtlandıktan sonra metabolik sendrom kriterleri arasına bel çevresi ölçümü de dahil edilmiştir. Nitekim çalışmamızda gruplar arası medyan VKi değerleri arasında anlamlı fark saptanmazken, hasta grubunun bel çevresi medyan değeri 100, kontrol grubunun medyan bel çevresi değeri 92 idi ve aralarındaki fark istatistiksel olarak anlamlıydı.

Çalışmamızda hasta grubunda \%58, kontrol grubunda \%34 sigara içme alışkanlığı mevcuttu ve bu fark istatistiksel olarak anlamlıydı. Psoriasis olgularında sigara içme alışkanlığı, sosyal sorunlar, depresif duygu durumu, kendine güvenin azalması gibi sebeplerle sağlıklı popülasyona göre daha yüksektir24.

Görüldüğü üzere, metabolik sendrom ve komponentleri olan DM, obezite, HT, dislipideminin psoriasisle yakın bir neden-sonuç ilişkisi mevcuttur. Bu nedenle psoriatik olguların, takip ve tedavileri süresince bu unsurların göz önünde bulundurularak izlenmesinin olası komorbiditeleri engelleyebileceği kanısındayız.

\section{Kaynaklar}

1. Kerkhof VCP, Schalkwijk J: Papulosquamous and eczematous dermatoses Dermatology. Ed. Bolognia JL, Jorizzo JL, Rapini RP. 2. Baskı. İspanya, Mosby Elsevier 2008;115-135

2. Gudjonsson EJ, Elder TJ. Psoriasis Fitzpatricks' Dermatology in general medicine. Ed. Wolff K, Goldsmith AL, Katz IS, Gilchrest AB, Paller SA, Leffell JD. 7. Baskı. Mcgraw-hill company 2008;169-193.

3. Al-Mutairi N, Al-Farag S, Al-Mutairi A, Al-Shiltawy M: Comorbidities associated with psoriasis: An experience from the Middle East. J Dermato 2010;37:146-55 
4. Kim N, Thrash B, Menter A: Comorbidities in psoriasis patients. Semin Cutan Med Surg 2010;29:10-5.

5. Arslan M, Atmaca A, Ayvaz G, ve ark. Türkiye Endokrinoloji ve Metabolizma Derneği Metabolik Sendrom Kılavuzu 2009.

6. Hu FB, Meigs JB, Li TY, Rifai N, Manson JE: Inflammatory markers and risk of developing type 2 diabetes in women. Diabetes 2004;53:693-700.

7. Hanley AJ, Festa A, D'Agostino RB, et al: Metabolic and inflammation variable clusters and predictions of type 2 diabetes: factor analysis using directly measured insülin sensitivity. Diabetes 2004;53:1773-81.

8. Filizci N, Aydın O, Bozdağ EK: Psoriasis vulgarisli hastalarda lipid profili, lipoprotein-a, apoprotein A ve B düzeylerinin PASI ile korelasyonunun değerlendirilmesi. Türkiye Klinikleri J Dermatol 2005;15:175-9.

9. Uyanık SB, Arı Z, Onur E, Gündüz K, Tanülkü S, Durkan K: Serum lipids and apolipoproteins in patients with psoriasis. Clin Chem Lab Med 2002;40:65-8.

10. Pişkin S, Gürkök F, Ekuklu G, Şenol M: Serum lipid levels in psoriasis. Yonsei Med J 2003;44:24-6.

11. Çelik R, Derviş E, Balaban $D$, Can G: Psoriasisli hastalarda metabolik sendrom birlikteliği. Türkderm 2010;44:204-8.

12. Drateln RC, Abundis ME, Munoz BRB, Saldana BR, Ortiz GM: Lipid profile, insulin secretion and insulin sensitivity in psoriasis. Am Acad Dermatol 2003;48:280-4.

13. Christophers E: Comorbidities in psoriasis. Clin Dermatol 2007;25:529-34.

14. Uçak S, Ekmekçi T, Başat O: Comprassion of various insulin sensitivity indices in psoriatic patients and their relationship with types of psoriasis. J Eur Acad Dermatol Venerol 2006;20:517-22.

15. Prey $S$, Bronsard V, Puzenat $E$, et al: Cardiovascular risk factors in patients with plaque psoriasis.a systemic review of epidemiological studies. J Eu Acad Dermatol Venerol 2010;24:23-30.
16. Cohen $A D$, Gilutz $H$, Henkin $Y$, et al. Psoriasis and the metabolic syndrome Acta Derm Venerol 2007:87:506-9.

17. Davidovici BB, Sattar N, Jörg PC, et al: Psoriasis and systemic inflammatory diseases: potential mechanistic links between skin disease and co-morbid conditions. J Invest Dermatol 2010;130:1785-96.

18. Love JT, Qureshi AA, Karlson WE, Gelfand MJ, Choi KH: Prevalance of the metabolic syndrome in psoriasis. Arch Dermatol 2011;147:419-24.

19. Pereira RP, Silva SA, Rebelo I, Figueiredo A, Quintanilha A, Teixeira F: Dislipidemia and oxidative stres in mild and in severe psoriasis as a risk for cardiovascular disease. Clin Chim Acta 2001;303:33-9.

20. Menter A, Griffiths CE,Tebbey PW, Horn JE, Stery W: Exploring the association between cardiovascular and other disease related risk factors in the psoriasis population: the need for increased understanding across the medical community. J Eur Acad Dermatol Venerol 2010;24:1371-7.

21. Cohen AD, Drehier J, Shapiro $Y$ et al: Psoriasis and diabetes: a population based cross sectional study. J Eur Acad Dermatol Venerol 2008;22:585-9.

22. Balcı A, Balcı DD, Yönden $Z$, et al: Increased amount of visceral fat in patients with psoriasis contributes to metabolic syndrome. Dermatology 2010;220:32-7.

23. Herron DM, Hinckley M, Hoffman SM, et al: Impact of obesity and smoking on psoriasis presentation and management. Arch Dermatol 2005;141:152734.

24. Lin WH, Wang HK, Lin CH: Increased risk of acute myocardial infarction in patients with psoriasis: A 5 year population based study in Taiwan. J Am Acad Dermatol 2011;64:495-501. 